\title{
DESCRIPTIVE STUDY OF TEACHER PROFESSIONALISM IN LEARNING PROCESS AT MTS NEGERI BAKALAN RAYUNG OF JOMBANG
}

\author{
Nur Fatimah
}

\begin{abstract}
Nur Fatimah (2017) "Descriptive Study of Teacher Professionalism in Learning Process at MTs Negeri Bakalan Rayung of Jombang"

Keywords: Descriptive Study, Learning Process, Teacher Professionalism

Professional teachers are the determinants of education process quality. In order to become professional teachers, they must be able to find to identity and actualize themselves in accordance with the abilities and rules of professional teachers. This research will find the answer of the formula: first, describe what factors can support the professionalism of teachers at MTs Negeri Bakalan Rayung of Jombang; second, describe how the professionalism of teachers in the learning process at MTs Negeri Bakalan Rayung of Jombang, third, describe how the principal's efforts in improving teachers professionalism in the learning process at MTs Negeri Bakalan Rayung Jombang.

This type of research was qualitative, and the method of data collection was by using observation, documentation and interview, while the analysis data were inductive, deductive and comparative.

The results of this study could be concluded: firstly, the ability of teachers professionalism at MTs Negeri Bakalan Rayung, Jombang was the ability in mastering materials / learning materials, managing teaching and learning programs, managing classes, using media, mastering the foundation of education, managing the interaction of teaching and learning, , recognizing the function of guidance and counseling, know and organize the school administration very well; secondly, the ability of teachers in preparing for teaching is also in very good category. It was indicated that the teacher had prepared the teaching preparation with the correct procedure, each sub chapter of discussion, the teacher had been able to use the instructional media in accordance with its function in delivering the material, and conduct evaluation in every learning process well; thirdly, the effort to improve the teachers professionalism in madrasah is done by the principal and teacher concern. Efforts that had been made by the principal, among others, by holding meetings, upgrading class teachers, and establishing the discipline enforcement on teachers and employees, holding regular meetings among teachers in the field of study and conduct self-assessment.
\end{abstract}




\section{A. Introduction}

In this era of development and developing country like Indonesia, teachers realize that their position is a respectable and noble profession. Teachers devote themselves to the intellectual life of the nation and improve the quality of the Indonesian people as a whole that is having faith, devoting to God, having noble attitude and mastering IPTEKS (science and technology) in realizing a quality society. Teachers are called ideal when always performing professionally with the main task is to educate, to guide, to train and to develop curriculum tools that can create conditions and a conducive learning atmosphere that is fun learning atmosphere, interesting, giving sense of security, giving space for learners to think actively, creatively and innovatively in exploring and elaborating ability. As the Javanese wise quote of "ing ngarso sung tulodho, ing madya mangun karso, tut wuri handayani". This means that when a teacher is in front, he must be able to provide good examples, as in the middle, he must be able to provide initiative and as behind he must be able to give encouragement or motivation. ${ }^{1}$

Professional teachers are the determinants of qualified educational processes. In order to become professional teachers, they must be able to find the identification and actualize themselves in accordance with the abilities and rules of professional teachers. Teachers are at the forefront of learning activity success in schools that are directly involved in planning and implementing learning activities. The quality of learning activities done is very dependent on the planning and implementation of the learning process undertaken by the teachers. Teachers' duties are not merely teaching (teacher centered), but rather to educate learners (children centered). Learning is essentially a process of interaction toward all the situations exist around individual learners. Learning can be viewed as a process directed towards the goal and process of doing through various learning experiences designed and prepared by the teachers. Learning is also a process of seeing, observing and understanding everything around the learners.

1 Rusman, Model-model Pembelajaran Mengembangkan profesionalisme Guru, (Jakarta : Raja Grafindo Persada, 2010), 15. 
Learning activities are conducted by two doers namely teachers and learners. Teacher's action is learned, and learners' action is learning. The learning action is related to the design and application of learning models. So it is able to create learning conditions that are challenging the creativity and activities of learners, motivating learners, and using multimedia, multi methods and multi sources in order to achieve the expected learning objectives and ensure the success of education. ${ }^{2}$

The competencies that must be possessed by a professional teacher include: pedagogic competence, personal competence, professional competence and social competence. Pedagogic competence is the ability to manage the learners learning that include learners understanding, design and implementation of learning, evaluation of learning outcomes and development of learners to actualize the various potentials they have. Personal competence is the personality ability that is stable, mature, wise and authoritative, possible to be an example for other learners and having noble attitude. Professional competence is the ability to master learning materials widely and deeply that enables to guide learners to meet the competence standards set out in the Education National Standards (SNP, explanation of Article 28 part 3 point c). Social competence is the ability of the teacher as part of the society to communicate and get along effectively with the learners, among the educators, education officers, parents / learner guardians and the surrounding community.

The four competencies mentioned above are very obvious, greatly affect the teaching and learning process, but the most basic that must be owned by the teachers is the professional competence. This professional competence requires a capability in realizing and fostering cooperation with all parties who are responsible for the process of child education. The cooperation is organized by parents, school leaders, surrounding communities and even with pupils faced everyday. ${ }^{3}$

2 lbid., 20.

3 Hadari Nawawi, Organisasi Sekolah dan Pengelolaan Kelas Sebagai Lembaga Pendidikan, (Jakarta : CV Haji Masagung, 1989), 126-127. 
Criteria of professional competence of teacher are as follows: mastering the materials, structures, concepts and scientific thinking patterns that support subject matter taught, mastering the competence standard and basic competence of subjects/fields of development taught, developing creative subject matter creatively, developing professionalism in a sustainable manner by taking reflective action, and utilizing information and communication technology to communicate and develop themselves. ${ }^{4}$

The position of the teacher requires not only the special ability of the teacher in the sense of mastering academic knowledge and professional proficiency relevant to his field of duties as a teacher, but also at a high level of maturity and responsibility and independence. These capabilities make the teacher has more value and high authority over the learner.

Teachers are one of the human components in teaching and learning process that play an important role in the effort of formatting human resource (HR). Therefore, teachers as one element in the field of education must play an active role and place the position as professionals, in accordance with the growing demands of society. This can mean that every teacher has the responsibility to bring the learners on a maturity or certain level of maturation. In this framework, the teacher is not just teaching that only as transfer of knowledge, but also must be a learning manager as an educator and mentor who provide guidance to guide learners in learning. ${ }^{5}$

Admittedly or not, the teacher will always be an important element that determines the success or failure of education. The teacher is the second person after the parent who always educates and supervises the children to get their ideals and goals of life. Therefore, the teacher must have a very high dedication and the profession he chose is not a side job because the teacher determines the success of children.

4 Rusman, Model-model, 58. 
Not all adults can be categorized as educators or teachers because the teachers must have some requirements that must be met. As stipulated in the Law of the National Education System, that to be appointed as a teacher, an educator, he must have minimum qualifications and certification in accordance with the level of teaching authority that is healthy physically and spiritually, and having the ability to realize the goals of national education. ${ }^{6}$

The teacher role in the learning process is felt very great influence on the change of the learner behavior. To be able to change the student behavior in accordance with the expection then it is required a professional teacher. The teacher must be able to use the components of education that the education process can run well.

Concerning the importance of teacher professionalism has been mentioned in the Qur'an as in the surah of Al-An'am verse 135 as follows:

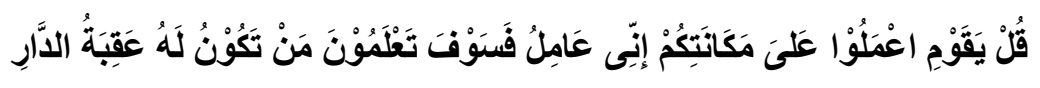

Meaning: "Say My people, do your utmost ability, I will do (too). Later you will know who (among us) will get good results from this world."

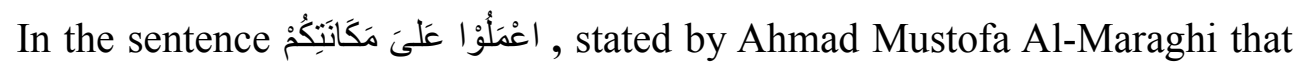
the sentence above implies that a person must work in accordance with the ability and expertise of each so that they are able to handle his job and able to develop all the potential that is in him for the progress of the work. And they will always get guidance from Allah SWT. ${ }^{88}$

From the above work can be known that the teacher professionalism is very important in implementing the teaching and learning process to achieve educational

6 Undang-Undang Sistem Pendidikan Nasional, (Bandung : Citra Umbara, 2003), 29.

7 Depag RI, Al-Qur'an dan Terjemahnya, (Jakarta : PT Intermasa, 1980), 210.

$8^{8}$ Ahmad Mustofa Al Murpighi, Terjemahan Tafsir Al Maraghi, (Semarang : Toha Putra, 1986), 98. 
goals. This professionalism is felt very important along with the development of science and technology. So the quality of education and professionalism of teachers has a very close relationship and mutual influences the process of achieving educational goals. If a teacher has a high professionalism in education, then automatically the quality of education will be high as well. So this will affect the future of students themselves, the nation, and state.

Based on the background of problems that have been described, it can be put forward the following problem formulation: first, what factors can support the teacher professionalism at MTs Negeri Bakalan Rayung Jombang; second, how the description of teacher professionalism in the learning process at MTs Negeri Bakalan Rayung Jombang is; third, how the principal's efforts on improving the teacher professionalism in the learning process at MTs Negeri Bakalan Rayung Jombang is.

\section{B. Method}

Research method is a process or a way essentially aims to find, develop or test the validity of in a study. This research is classified on qualitative research that is research procedure that produces descriptive data in the form of written or oral words from people and behavior that can be observed. ${ }^{9}$

\section{Type of Research}

In writing this study, the author used two kinds of research, namely:

\section{a. Library Research}

The literature study has been undertaken to solve a problem that relies on an in-depth critical review of the relevant literature. The literature review thesis contains a topic in which contains some ideas or propositions supported by data or information obtained from literature sources.

Materials (literature sources) can be removed from various sources such as research journals, dissertations, thesis, research reports, textbooks, papers,

$9^{12}$ Nurul Zuriah, Metodologi Penelitian Sosial dan Pendidikan, (Malang : Bumi Aksara, 2005), 92. 
seminar reports and scientific discussions of official publications or other institutions. ${ }^{10}$

\section{b. Field Research}

Field research is research conducted directly in the field. The advantage of this type of research is that researchers can obtain information as close as possible to the real world, so that the expected results of the research can utilize the results as well as possible and obtain data or information that is always up to date. ${ }^{11}$

\section{Object and Data Source}

In accordance with the formulation of the problems mentioned earlier, the object of this study was only directed to the teacher professionalism in the learning process.

The data source used as the object of this study was the primary data that is the data source that directly provide data to the data collector. The primary data in this study included data obtained from interviews with principal, vice principals, teachers and students at MTs Negeri Bakalan Rayung Jombang. Besides, there are secondary data, which is often also needed by the researcher. Secondary data is data obtained is a source that does not directly provide data to data collectors, for example through others or through documents, books / school library as literature and so forth. ${ }^{12}$

According to Lofland, as quoted by Lexy J. Moleong stated that the main data sources of qualitative research are the words and actions of the observed or interviewed people and other written documents or sources that constitute additional data. ${ }^{13}$

10 Universitas Negeri Malang, Pedoman, 14.

11 Restu Kartiko Widi, Asas Metodologi Penelitian, (Surabaya : Graha Ilmu, 2009), 52.

12 Sugiyono, Metode Penelitian Pendidikan, (Bandung : Alfabeta, 2010), 308-309.

13 Lexy J. Moleong, Metode Penelitian Kualitatif, (Bandung : Remaja Rosdakarya, 2006), 112. 


\section{Data Collection Method}

The process of data collection always occurs in a study. In the process was used several methods. The type of method chosen and used in data collection must be in accordance with the nature and characteristics of research undertaken. In order to the evidence and facts obtained were objective, valid and no deviations from the actual circumstances. Then, the method of data collection used in this study is as follows:

\section{a. Observation Method}

The method of observation is the deliberate and systematic study of social phenomena and psychic symptoms by way of observation of record data. ${ }^{14}$

In this case the author used the method of direct observation that held and record in the actual situation. This method was used by the researcher to observe directly about the state of research objects, conditions and infrastructure facilities, state of supporting facilities, teaching and learning process.

The object of qualitative research observed according to Spradley is called social situation, which consists of three components:

1) Place or where the interaction in a social situation is taking place. In education, it can be done in the classroom.

2) Actor, doers or people who are playing a certain role, like teachers, principal, supervisors, learner parents.

3) Activity or actions undertaken by actors in an ongoing social situation, such as teaching and learning activities. ${ }^{15}$

\section{b. Interview Method}

14 Kartini Kartono, Pengantar Metodologi Riset Sosial, (Bandung : Pustaka Setia, 1986), 142. 
Interview method is an oral conversation or questioning between two or more people who sit facing physically and directed at a problem. ${ }^{16}$

This method is used to obtain information from the data source that was the principal about the history of establishment, efforts to improve the teacher professionalism in teaching and learning process and other matters relating to the subject.

\section{c. Documentation Method}

Documentation method is to find data about things or variables in the form of notes, transcripts, books, newspapers, magazines, inscriptions, minutes, agenda and so forth. ${ }^{17}$

The purpose of this documentation method is the method of collecting data by quoting the writing or certain records that can provide evidence or information about an event. This method was used to obtain data about the geographic location of the school, organizational structure, number of teachers and number of employees.

\section{Data Analysis Technique}

Data analysis is a very important step in the research because the results of this study can be used to answer a problem formulation that has been proposed by the researcher. As for in this research, the researcher used data analysis technique as follows:

a. Inductive analysis is the process of organizing the results of a separate observation into a series of relations or a generalization. ${ }^{18}$

b. Descriptive analysis is to analyze and present facts systematically so it can be easier to understand. ${ }^{19}$

16 Ibid., 171.

17 Suharsimi Arikunto, Prosedur Penelitian Suatu Pendekatan Praktek, (Jakarta : Rineka Cipta, 1993), 236.

18 Saifuddin Azwar, Metode Penelitian, (Yogyakarta : Pustaka Pelajar, 1998), 40. 
c. Content analysis is the analysis by examining the documentation, records of the object under study. ${ }^{20}$

\section{Discussion}

The next step is the data that has been collected analyzed in order to get a clear picture in accordance with the purpose of this study. In order for the sequence of data analysis presented was arranged as the formulation of the problem, the data analysis was divided into three parts, the data used to measure factors that can support the teacher professionalism was placed at the beginning, then data that were analyzed to measure the professional ability of teachers, and the last, data about efforts to increase the pteacher rofessionalism. The data analysis is organized as follows:

\section{Supporting Factors of Teacher Profesionalism}

The achievement of educational goals is determined by the effective and efficient implementation of teaching as one aspect of education that must be pursued to achieve optimal educational goals. Achievement of educational goals determined so much whether good or not good planning, the executor, then with professional teachers it is expected that education will run smoothly as in the programm.

To find out the last teachers education level owned by MTs Negeri Bakalan Rayung Jombang can be seen that 64 respondents or $78.05 \%$ of teachers last education is a bachelor, while those have the last education from postgraduate as many as 18 respondents or $21.95 \%$ of teachers. Fortunately, there is not teachers at MTs Negeri Bakalan Rayung Jombang who are educated from senior high school and Diploma at all. The data shows that all teachers at MTs Negeri Bakalan Rayung Jombang have qualified as teachers, even some teachers have postgraduated education.

19 Ibid., 46.

20 Noeng Muhanjir, Metodologi Penelitian Kualitatif, (Yogyakarta : Rake Sarasin, 1996), 49. 
About the teaching experience, it was found that 64 respondents or $78.05 \%$ of teachers at MTs Negeri Bakalan Rayung Jombang had more than three years of teaching experience, while those have teaching experience ranged from one to three years as many as 16 respondents or $19.51 \%$ teachers. While those have less than one year of teaching experience numbered of 2 respondents or $2.44 \%$ of teachers.

Judging from the experience of teaching, most teachers MTs Negeri Bakalan Rayung Jombang has had a long working period. With this considerable working period they certainly have and have the opportunity to develop their professionalism, so they can carry out teaching tasks more steadily, and make it easier to improve their professional competence skills.

Furthermore, teacher education background will also affect the teachers professionalism. To find out whether appropriate or not the knowledge owned fit with the research results obtained data that 73 respondents or $89.02 \%$ of teachers have educational background based on what they teach at MTs Negeri Bakalan Rayung Jombang, then as many as 9 respondents or 10, $98 \%$ of teachers responded as they taught, and no respondents or $0 \%$ of teachers have the education do not match what they taught.

It can be said that the conformity level of education they take with the subjects they teach is good enough, no one has education that is not in accordance with the subjects he taught. But with the years of work, experience and training they have gained during teaching at MTs Negeri Bakalan Rayung Jombang, the teachers are expected to be able to deliver the material well and correctly.

\section{Teacher Professionalism Ability of MTs Negeri Bakalan Rayung Jombang}

The main task of a teacher as a professional is to carry out the task in the process of teaching and learning, that is by holding a direct interaction with learners when learning in the school. To know the task, the teacher must have basic skills or competencies which are a prerequisite of a teacher as supporting steps of teaching and learning process to be done well. 
From the results of the research known those 75 respondents or $91.5 \%$ of teachers at MTs Negeri Bakalan Rayung Jombang have mastered the teaching materials / learning materials in every teaching and learning process that will be delivered. From these results it can be said that the mastery level of teachers' materials before the teaching and learning process has good category. Mastery of teaching materials is very important because before a teacher teaches in front of the class, the mastery of this material is absolutely implemented by a teacher. By mastering the material, the teacher will easily bring the students and direct them to the objectives that have been programmed.

About the way of making good teaching planning, it can be concluded in accordance with the results of research that the teachers' preparation of teaching at MTs Negeri Bakalan Rayung Jombang can be categorized very well because in making preparation of teaching, a teacher must be based on GBPP (outline of teaching program), because it has been determined goals, time allocation, and evaluation of each competency in it. And in preparing the teaching, the teachers at MTs Negeri Bakalan Rayung Jombang have implemented it in accordance with the provisions of the educational base that is guided by the prevailing GBPP. The most ideal and good preparation of teaching is in each topic, so the teacher can explain each topic in detail and planned in accordance with the time allocation of each sub topic, but from the results of research it can be said that the making of lesson plans at MTs Negeri Bakalan Rayung Jombang has been good.

In the process of teaching and learning, the use of teaching methods is very important in order to achieve the learning objectives. Therefore, a teacher must use teaching method in teaching and learning process so the learners can accept what is delivered by teacher.

From the results of the study showed that 74 respondents or $90.25 \%$ of teachers always use teaching methods, and 8 respondents or $9.75 \%$ of teachers sometimes use them. Everyone basically wants to convey their ideas to others. In this case, the teachers can convey their ideas to the learners but they must use certain methods so that the idea can be delivered properly. 
Teaching methods in the learning process vary depending on the teachers' creativity, facilities, media, and what delivered (materials) is very influential on the teachers' success in conveying lessons to the learners. Various methods were used at MTs Negeri Bakalan Rayung Jombang including discussion, question and answer, giving tasks, demonstrations, and so forth.

The teachers' creativity at MTs Negeri Bakalan Rayung Jombang in the use of teaching methods has developed very well, as evidenced by the variety of methods used in conveying materials. Teaching methods used must be tailored to the material delivered so that a single material is possible delivered using several methods. To improve the quality of good teaching and learning further, the school must provide visual aids or media required. The situation and the availability of props at MTs Negeri Bakalan Rayung Jombang are very complete.

The process of teaching and learning using props is a very important thing because it works for the tool clarifies the subject in delivering the materials, and no respondents never use props. This can already be said in very good category. It means MTs Negeri Bakalan Rayung Jombang has been able to use props in delivering the subject matter to the students in good manner.

Conducting evaluation in the learning process is an integral or inseparable part that serves as a means of measuring the learners' success. Implementation of the evaluation is done before and after the lesson during the lesson, or within a certain timeframe like every three months and every six months. Evaluation is done by teachers at MTs Negeri Bakalan Rayung Jombang.

From the results of this study, the evaluation shows that most teachers have conducted the evaluation accurately and maximally, as evidenced by 80 respondents or $97.6 \%$ of teachers responded to evaluate before and after the lesson, and only 2 respondents or $2.4 \%$ of teachers conducted evaluation before the lesson. While the number of those has never conducted an evaluation at MTs Negeri Bakalan Rayung Jombang is $0 \%$. In other word, all teachersvat MTs Negeri Bakalan Rayung Jombang have conducted a very good evaluation. 


\section{Efforts to Improve Teacher Professionalism of MTs Negeri Bakalan Rayung} Jombang

Teacher professionalism is a major problem that a teacher must possess, because it is very closely related to teaching and learning activities and the teaching and learning success. The efforts to increase the teacher professionalism can be done by the principal or the teachers themselves.

The school principal has been trying to improve the teacher's knowledge well, but still need to develop by increasing the training and the others. The principal efforts to improve teachers' knowledge can be done in various ways, including through teacher meetings, teacher upgrading, and provision of infrastructure.

The results of research indicate that the principal's efforts to increase the teachers' knowledge; teacher meetings, upgrading and provision of infrastructure are good. This shows that the principal's efforts in improving the teachers'professional knowledge at MTs Negeri Bakalan Rayung Jombang have been very good and implemented in various ways, but it still need how the teacher's own efforts are; whether they can show the results of their efforts done by the principal or not.

The teachers discipline in carrying out the task is very important because it will greatly affect the success of the task and the achievement of teaching and learning objectives. To know the results, based on the results showed those 80 respondents or $97.6 \%$ of teachers always apply the work discipline, and 2 respondents or $2,4 \%$ of teachers sometimes apply discipline. There is no teacher who never applies the discipline in carrying out its duties. It can be analyzed that the teachers' discipline of MTs Negeri Bakalan Rayung Jombang is very good, but it still requires the increase of teachers' discipline from the principal so that all teachers and even employees can carry out self-awareness discipline.

From the result of the research also shows that 49 respondents or $59,8 \%$ of teachers try to improve their professionalism by learning through reading, book, media. Those who increase their professionalism by writing as many as 8 respondents or $9.7 \%$ teachers, continuing the higher education about 10 respondents or $12.2 \%$ teachers, and doing self-assessment as many as 15 
respondents or $18.3 \%$ of teachers. It can be analyzed that all teachers of MTs Negeri Bakalan Rayung Jombang have been trying to improve their teaching professionalism through reading or by self-study, writing papers, continuing education, and self-assessment. It can be concluded that the willingness of teachers in improving their professionalism has been very good.

\section{Conclusion}

From the results of research and data analysis can be concluded that the factors that can support the teacher professionalism at MTs Negeri Bakalan Rayung Jombang are the increase of teacher education level, the suitability of the teacher education department with the taught material, and the length of teaching or teaching experience of teachers.

1. The ability of teachers professionalism at MTs Negeri Bakalan Rayung Jombang is showed that the ability in mastering the material / learning materials, managing the teaching and learning program, managing the classroom, using the media, mastering the education foundation, managing the interaction of teaching learning, assessing the achievement of teaching learning, recognizing the function of guidance and counseling, knowing and organizing the school administration is very good.

2. The teacher ability in preparing teaching is also in very good category. This is marked by the teacher have made the teaching preparation with the correct procedure that is by making the teaching preparation refer to GBPP (outline of learning program) on every sub chapter of the discussion. The teachers of MTs Negeri Bakalan Rayung Jombang have been able to use instructional media in accordance with its function in delivering the material, as well as conducting evaluation in every learning process well.

3. Efforts to increase the teachers' professionalism at MTs Negeri Bakalan Rayung Jombang are conducted by the principal and teachers by themselves. Efforts that have been made by the principal are by holding meetings, upgrading class teachers, establishing the discipline enforcement on teachers and employees of MTs Negeri Bakalan Rayung Jombang, helding regular meetings among subject teachers, and conducting self-assessment. 


\section{REFERENCES}

Al Abrasyi, M., Athiyah, Dasar-dasar Pokok Pendidikan Islam, Jakarta : Bulan Bintang, 1979.

Al Barry, M., Dahlan,; Partanto, A., Pius, Kamus Ilmiah Populer, Surabaya : Arkola, 1994.

Aleida, Ida,; Sahertian, A., Pied, Supervisi Pendidikan Dalam Rangka Program Inservise Education, Surabaya : Usaha Nasional, 1990.

Al Murpighi, Mustofa, Ahmad, Terjemahan Tafsir Al Maraghi, Semarang : Toha Putra, 1986.

Arifin, M., Kapita Selekta Pendidikan Islam dan Umum, Bandung : Pustaka Pelajar, 1996.

Arikunto, Suharsimi, Prosedur Penelitian Suatu Pendekatan Praktek, Jakarta : Rineka Cipta, 1993.

Azwar, Saifuddin, Metode Penelitian, Yogyakarta : Pustaka Pelajar, 1998.

Darajat, Zakiah, Ilmu Pendidikan Islam, Jakarta : Bumi Aksara, 1992.

Indrakusuma, Daim, Amin, Pengantar Ilmu Pendidikan, Surabaya : Usaha Nasional, 1973.

Kunandar, Guru Profesional, Jakarta : Raja Grafindo Persada, 2010.

Kartono, Kartini, Pegantar Metodologi Riset Sosial, Bandung : CV Pustaka Setia, 1986.

Marimba, D., Ahmad, Pengantar Filsafat Pendidikan Islam, Surabaya : Al Ma'arif, 1980.

Moleong, J., Lexy, Metode Penelitian Kualitatif, Bandung : Remaja Rosdakarya, 2006.

Muhanjir, Noeng, Metodologi Penelitian Kualitatif, Yogyakarta : Rake Sarasin, 1996.

Nasution, Teknologi Pendidikan, Bandung : Jenmers, 1962.

Nawawi, Hadari, Organisasi Sekolah dan Pengelolaan Kelas Sebagai Lembaga Pendidikan, Jakarta : Haji Masagung, 1989.

Nurdin, Syafrudin, Guru Profesional dan Implementasi Kurikulum, Ciputat : Pres, 2002.

Poerwadarminto, WJS.; Wojowasito, S., Kamus Bahasa Inggris Indonesia-Indonesia Inggris, Bandung : Hasta, 1982. 
Purwanto, Ngalim, Administrasi dan Supervisi Pendidikan, Bandung : Remaja Rosdakarya, 1993.

RI Depag, Al-Qur'an dan Terjemahnya, Jakarta : PT Intermasa, 1980.

Roestiyah, N., K., Masalah-masalah Ilmu Keguruan, Jakarta : Bina Aksara, 1986.

Rusman, Model-model Pembelajaran Mengembangkan Profesionalisme Guru, Jakarta : Raja Grafindo Persada, 2010.

Rusyan, A., Tabrani,; Wijaya, Cece, Kemampuan Dasar Guru Dalam Proses Belajar Mengajar, Jakarta : Rajawali, 1991.

Saifullah, Ali, Antara Filsafat dan Pendidikan, Surabaya :Usaha Nasional, 1989.

Sudirman, A., M., Interaksi dan Motivasi Belajar, Jakarta : Rajawali Pres, 1991.

Sudjana, Nana, Dasar-dasar Proses Belajar Mengajar, Bandung : Sinar baru, 1991.

Sugiyono, Metode Penelitian Pendidikan, Bandung : Alfabeta, 2010.

Surakhmad, W., Pengantar Interaksi Belajar Mengajar, Bandung : Transito, 1980.

Surya, M., dkk, Kapita Selekta Kependidikan SD, Jakarta : Universitas Terbuka, 2003.

Tafsir, Ahmad, Ilmu Pendidikan Islam Dalam Perspektif Islam, Bandung : Rajawali Rosdakarya, 1991.

Tim Pembina Matakuliah Didaktik Metodik, Kurikulum PBM, Surabaya : IKIP Surabaya, 1981.

Tim Penyusun Kamus Pusat Bahasa, Kamus Bahasa Indonesia, Jakarta : Pusat Bahasa, 2008.

Undang-undang Sistem Pendidikan Nasional, Bandung : Citra Umbara, 2003.

Universitas Negeri Malang, Pedoman Penulisan Karya Ilmiah, Malang : Biro Administrasi Akademik, 2000.

Usman, Uzer, Moh., Menjadi Guru Profesional, Bandung : Remaja Rosdakarya, 1994.

Vebrianto, St., Kapita Selekta Pendidikan, Yogyakarta : Yayasan Pendidikan Paramita, 1984.

Widi, Kartiko, Restu, Asas Metodologi Penelitian, Surabaya : Graha Ilmu, 2009.

Zuriah, Nurul, Metodologi Penelitian Sosial dan Pendidikan, Malang : Bumi Aksara, 2005. 